\title{
Comments on the special issue on tropical crops of FASE
}

\author{
Luiz J C B CARVALHO (ه) \\ Embrapa Genetic Resources and Biotechnology Center, Brasilia 70770-901, Brazil
}

The issues of tropical crop domestication, genetic diversity of edible part (nutritive values) are of major concerns for topical crops, especially in order to high light the domestication syndrome processes of non-seeds crops as sources of food for humans. The title examples authors listed and the ones added here strengthen the utilization of modern genomics [Zhiqiang XIA et al. Comparative transcriptomics revealed enhanced light responses, energy transport and storage in domestication of cassava (Manihot esculenta). DOI: 10.15302/J-FASE-2016126; Yuhua FU et al. A bacterial artificial chromosome-based physical map of Manihot esculenta ssp. Flabellifolia. DOI: 10.15302/J-FASE-2016124], transcriptomic (Yang ZHANG et al. Annotation and validation of genes involved in photosynthesis and starch synthesis from a Manihot full-length cDNA library. DOI: 10.15302/J-FASE-2016113 $)^{[1,2]}$, proteomics ${ }^{[3]}$, new genetic resources $^{[4-6]}$, and biotechnology (Maliwan NACONSIE and Peng ZHANG. Transgenic technologies in cassava for nutritional improvement and viral disease resistance: a key strategy for food security in Africa. DOI: 10.15302/J-FASE$2016119)^{[7]}$ toward cassava crop as a tropical plant model for storage root and tuber human edible part.

\section{References}

1. Souza D A P A, Carvalho, CRB. Assessing global gene expression change in storage root of cassava landraces diversity using microarray data. Poster at Scientific Conference of the Global Cassava Partnership for the Century-Gcp21-Ii, 2012

2. An F, Chen T, Stéphanie D M A, Li K, Li Q X, Carvalho L J C B, Tomlins K, Li J, Gu B, Chen S. Domestication syndrome is investigated by proteomic analysis between cultivated cassava (Manihot esculenta Crantz) and its wild relatives. PLoS One, 2016, 11(3): e0152154

3. An F, Li G, Li Q X, Li K, Carvalho L J C B, Ou W, Chen S. The comparatively proteomic analysis in response to cold stress in cassava plantlets. Plant Molecular Biology Reporter, 2016, 34(6): 1095-1110

4. Carvalho L J C B, Agustini M A V, Anderson J V, Vieira E A, de Souza C R B, Chen S B, Schaal B A, Silva J P. Natural variation in expression of genes associated with carotenoid biosynthesis and accumulation in cassava (Manihot esculenta Crantz) storage root. BMC Plant Biology, 2016,16 (1): 133

5. Carvalho L J C B, de Almeida J D, Anderson J V, Vieira E A, Chen S, Batista de Souza C R, Fuhrmann E, Padilha da Silva J. Studies on variation of carotenoid protein content in cassava (Manihot esculenta Crantz) storage root reveal implications for breeding and the use of induced mutations. Plant Mutation Reports, 2013, 3(1): 25-36

6. Yan H, Lu L, Hershey C, Ceballos H, Chen S, Li K. Cassava mutation breeding: current status and trends. Plant Mutation Reports, 2013, 3(1): 3744

7. Carvalho L J C B, Vieira E A, de Freitas Fialho J, de Souza C R B. A genomic assisted breeding program for cassava to improve nutritional quality and industrial traits of storage root. Crop Breeding and Applied Biotechnology, 2011, 11(4): 289-296

Received December 24, 2016; accepted December 26, 2016

Correspondence: luiz.castelo@embrapa.br

CC The Author(s) 2016. Published by Higher Education Press. This is an open access article under the CC BY license (http://creativecommons.org/licenses/by/4.0) 


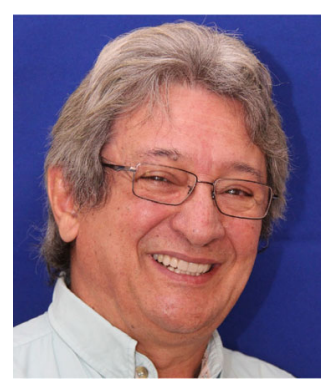

Luiz J C B CARVALHO, graduated as an agronomist from Federal University of Vicosa-MG, Brazil. He obtained M.Sc. degree from University of Florida, Gainesville, and Ph.D. degree from Cornell University, Ithaca. He spent two years (1994-1996) at Washington University in Saint Louis, St. Louis (MO), as visitor researcher through a Rockefeller Foundation Post-Doc Fellowship. He also received research scholarship from the Brazilian National Science Council (1991-1994), the Rockefeller Career Fellowship in Cassava Biotechnology (19972000) and the Embrapa National Project Leadership Award, category Technical Quality-2000. He was a former member of the Cassava Biotechnology Network Board, representing Latin America and Caribbean (1997-2000), and is a current member of the Post-Graduation Committee for the Biochemistry and Cellular Biology Department, University of Brasilia, DF. He has become an Embrapa research scientist since 1983, first, at the Cerrados Center and later, at the Genetic Resources and Biotechnology Center. His current research area is focused on the use of plant biodiversity for sustainable agriculture with particular interest in the diversity of the genus Manihot in Brazil, center of diversification and domestication of cassava. His work provides fundamental information on genetic diversity, plant biochemistry, plant molecular genetics and biology to study variations on the storage mechanisms of sugars, starch, proteins and carotenoids in cassava storage roots. The information acquired has been used to regulte storage mechanisms and improve root traits or add product value to cassava crop in a traditional breeding program at EMBRAPA_CERRADOS. Over the last five years, Dr Carvalho published nearly 40 articles, including scientific papers, short communications and book chapters in high ranked international scientific journals and conferences. 